\title{
28 Research Suare \\ Is It Time to Recast India's Fiscal and Monetary \\ Policy Frameworks?
}

\section{Dinesh Kumar Srivastava}

EY

Muralikrishna Bharadwaj

EY

Tarrung Kapur

EY

Ragini Trehan ( $\nabla$ ragini.trehan@in.ey.com )

EY

\section{Research}

Keywords: India's economic growth, Fiscal Policy, Monetary Policy, India's FRBMA, Fiscal Responsibility Legislation, Monetary Policy Committee, Fiscal Council, Internal inconsistency, India's debt sustainability, Macro Policy Coordination Council

Posted Date: September 8th, 2020

DOl: https://doi.org/10.21203/rs.3.rs-70017/v1

License: (c) (i) This work is licensed under a Creative Commons Attribution 4.0 International License.

Read Full License 


\section{Is it time to recast India's fiscal and monetary policy frameworks?}

Authors:

\section{D.K. Srivastava}

Chief Policy Advisor, EY India and formerly Director, Madras School of Economics Address: Golf View Corporate Tower B, Sector 42, Sector Road, Gurugram - 122002 Tel: + 911244434000

Contact: +91 9560065860; dkscloud@gmail.com, dk.srivastava@in.ey.com

\section{Muralikrishna Bharadwaj}

Senior Manager, EY India

Address: Golf View Corporate Tower B, Sector 42, Sector Road, Gurugram - 122002 Tel: + 911244434000

Contact: +91 9704362387; muralikrishna.B@ in.ey.com

\section{Tarrung Kapur}

Manager, EY India

Address: Golf View Corporate Tower B, Sector 42, Sector Road, Gurugram - 122002 Tel: + 911244434000

Contact: +91 9650518555; tarrung.kapur@in.ey.com

\section{Ragini Trehan (corresponding author)}

Manager, EY India

Address: Golf View Corporate Tower B, Sector 42, Sector Road, Gurugram - 122002 Tel: + 911244434000

Contact: +91 9962630238; ragini.trehan@in.ey.com 


\title{
Is it time to recast India's fiscal and monetary policy frameworks?
}

\author{
D.K. Srivastava, Muralikrishna Bharadwaj, Tarrung Kapur, Ragini Trehan
}

\begin{abstract}
With the onset of the Coronavirus disease (COVID-19) pandemic, a number of macro parameters of the Indian economy have been thrown out of gear. The fiscal deficit on the combined account of centre and state governments in 2020-21 may increase to $11-12 \%$ of estimated GDP. Consequently, the combined debt-GDP ratio of the central and state government may reach close to $81 \%$ of GDP at the end of 2020-21, more than $20 \%$ points above the targeted threshold of $60 \%$ as per centre's 2018 amendment to the Fiscal Responsibility and Budget Management Act (FRBMA). The CPI inflation rate breached the upper tolerance limit of the monetary policy framework (MPF) in the last quarter of 201920 and the first quarter of 2020-21. In fact, India's economic crisis predates the pandemic. The infirmities of the FRBMA and the MPF had already started becoming visible with 2019-20 real and nominal GDP growth rates plummeting to $4.2 \%$ and $7.2 \%$ respectively. It is high time that we consider recasting India's fiscal and monetary policy frameworks. In this article, we review these frameworks, identify their inconsistencies, and consider remedial changes so as to serve India' future needs and compulsions.
\end{abstract}

India's economic growth, Fiscal Policy, Monetary Policy, India's FRBMA, Fiscal Responsibility Legislation, Monetary Policy Committee, Fiscal Council, Internal inconsistency, India's debt sustainability, Macro Policy Coordination Council 


\section{Is it time to recast India's fiscal and monetary policy frameworks?}

\section{D.K. Srivastava, Muralikrishna Bharadwaj, Tarrung Kapur, Ragini Trehan}

\section{Introduction}

The combined fiscal deficit of central and state governments may turn out to be in the range of $11-12 \%$ of GDP ${ }^{1}$ in 2020-21 leading to a sharp upsurge in the debt-GDP ratio. This will lead to a significant departure from the target debt-GDP ratio of $60 \%$ for the combined government as per the centre's 2018 amendment to the Fiscal Responsibility and Budget Management Act (FRBMA). The CPI inflation rate has also breached the upper tolerance limit of $6 \%$ in the last quarter of 2019-20 and the first quarter of 2020-21. In July 2020, the CPI inflation rate was 6.9\%. While the immediate impact is that of COVID, even prior to the pandemic, India's macroeconomic parameters were slipping with real and nominal GDP growth falling well below desired levels in $2019-20$ at $4.2 \%$ and $7.2 \%$ respectively. In the light of the current challenges and India's future needs, it is an opportune time to review and recast India's macro policy frameworks consisting of fiscal and monetary policies.

After the introductory section 1, section 2 deals with the key features of the fiscal policy framework as it evolved from 2003 onwards and as it stands presently after the 2018 amendment. This section highlights the impact of centre's FRBMA and some of its internal inconsistencies particularly after the 2018 amendment. Section 3 undertakes a review of India's MPF which took shape in 2015. This section highlights India's inflation experience after the adoption of the MPF and its implications for nominal growth. Section 4 follows up by providing a review of India's growth experience in real and nominal terms including an analysis of the structural and cyclical reasons underlying the fall in trend growth as also a very sharp fall in actual growth in recent years respectively. Section 5 discusses the coordination issues between monetary and fiscal policy frameworks including some inbuilt inconsistencies in their implicit assumptions. Section 6 then provides the relevant considerations for modifying fiscal and

\footnotetext{
${ }^{1}$ The IMF, in its World Economic Outlook Update released in July 2020 projected India's general government fiscal deficit at $12.1 \%$ of GDP for FY21. The World Bank, its recent release of India Development Outlook released in July 2020 has projected a general government fiscal deficit of $11.1 \%$ of GDP.
} 
monetary policy frameworks individually while keeping in mind mutual consistency and coordination issues. Section 7 provides a summary and concluding observations.

\section{Fiscal policy framework: evolution and key features}

The central government had enacted a FRBMA in 2003. This Act has been amended a number of times since its inception. The latest amendment was in 2018. Centre's FRBMA was supplemented by Fiscal Responsibility Legislations (FRLs) of the state governments which were legislated during 2002 to 2007 for 26 states, and in 2010, for West Bengal and Sikkim.

In the 2003 FRBMA read with its Rules, centre's fiscal deficit to GDP ratio was targeted at 3\% and the revenue account was to be kept in balance or in surplus. The 2018 amendment changed the target variable to debt-GDP ratio and used the fiscal deficit-GDP ratio only as an operational target. The objective of revenue account balance was given up. For the combined account of centre and state governments, the debt-GDP ratio target was kept at $60 \%$ with centre's share at $40 \%$ and states' share at $20 \%$. The central government was given a countercyclical role with a flexibility of $0.5 \%$ points of GDP in its fiscal deficit-GDP ratio subject to certain conditions and rules.

The state governments had enacted their FRLs individually following the guidance given by the Twelfth Finance Commission (12 FC). Although some of them amended their respective FRLs from time to time, their basic features remained the same while changing the target dates. Some of the important features of the state FRLs related to limiting the fiscal deficit to GSDP ratio to $3 \%$ and keeping the revenue account in balance if not in surplus. The $12 \mathrm{FC}$ had given an indicative benchmark of $28 \%$ as the debt-GSDP target for states. Correspondingly, the benchmark value for interest payment to revenue receipts was provided at $15 \%$. Even though the central government amended its FRBMA in 2018, the state governments did not bring about corresponding changes in their respective FRLs which would have required reducing their individual debt-GSDP ratios to $20 \%$.

Trends in fiscal imbalance of Centre and states 
Chart 1 shows the fiscal deficit of centre and states during the period 2000-01 to 2019-20. In the case of centre, there was some initial success with centre's fiscal deficit falling to $2.6 \%$ of GDP in 2007-08, the only year in which it was below the FRBM target of 3\% of GDP. Fiscal deficit relative to GDP sharply rose to $6.1 \%$ and $6.6 \%$ in $2008-09$ and $2009-10$ respectively partly in response to the 2008 global economic and financial crisis. After that, although there was a steady reduction, it could not be brought down to the targeted level. Instead, the central government resorted to postponing the target dates. In 2019-20, centre's fiscal deficit increased to 4.6\% of GDP. In 2020-21, it is expected to rise to a range of $6-7 \%$ of estimated $\mathrm{GDP}^{2}$. States, considered together, have been more successful in keeping their fiscal deficit below 3\% of GDP. After 2004-05, there are three years namely, 2009-10, 2015-16, and 2016-17 in which states' combined fiscal deficit was above 3\% of GDP.

\section{Chart 1: fiscal deficit (+) relative to GDP: Centre and states}

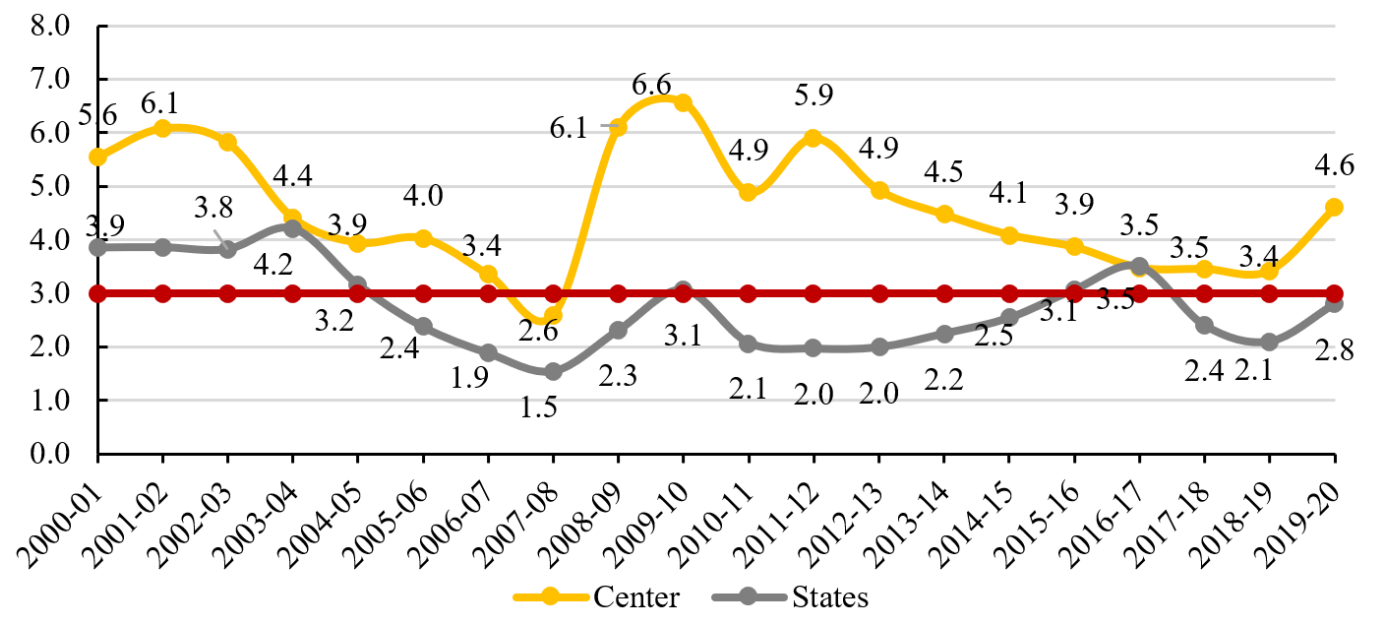

Source (Basic Data): IPFS, CSO, RBI 2019-20 Annual Report (released 25 August 2020)

Note: For states, data from 2016-17 onwards is sourced from the RBI where 2019-20 pertains to RE

With respect to the revenue account, the centre's budget went into deficit in 1979-80 and has remained in deficit in all years since then. The aggregate account of the states went into revenue deficit in 198788 on a persistent basis. It remained in deficit until 2005-06. Post that, there was either a surplus or a marginal deficit (Chart 2). In this analysis, revenue deficits and surpluses of individual states are aggregated together to arrive at the combined revenue deficit of states.

\section{Chart 2: Revenue deficit (+) relative to GDP: Centre and states}

\footnotetext{
${ }^{2}$ These numbers are estimated using the 2011-12 base new GDP series.
} 


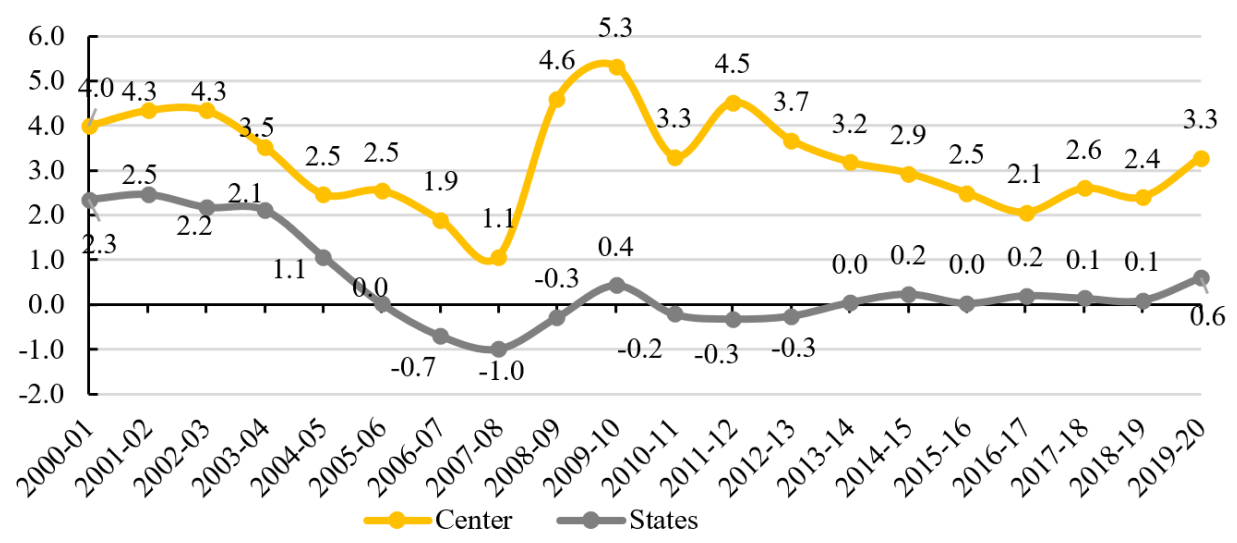

Source (Basic Data): IPFS, CSO, RBI 2019-20 Annual Report (released 25 August 2020)

Note: For states, data from 2016-17 onwards is sourced from the RBI where 2019-20 pertains to RE.

\section{Impact of slippage in fiscal deficit on the debt-GDP ratio}

The debt-GDP ratio at the end of a fiscal year depends on three factors: (a) level of fiscal deficit in the current year $\left(\boldsymbol{f}_{\boldsymbol{t}}\right)$, (b) debt-GDP ratio of the previous year $\left(\boldsymbol{b}_{t-1}\right)$, and (c) nominal growth rate of the current year $\left(\boldsymbol{g}_{\boldsymbol{t}}\right)$. The increase in debt-GDP ratio between two successive years $\left(\boldsymbol{b}_{\boldsymbol{t}}-\boldsymbol{b}_{t-1}\right)$ would be higher if (i) the current fiscal deficit is higher, (ii) the current nominal growth rate is lower, and (iii) the previous year's debt-GDP ratio is lower. The relevant relationship is given below with variables defined as above.

$b_{t}-b_{t-1}=f_{t}-b_{t-1}\left[\frac{g_{t}}{\left(1+g_{t}\right)}\right]$

Accordingly, in Table 1, we have estimated the likely level of debt-GDP ratios of the centre, the states and their combined account. With the nominal GDP growth plummeting in 2019-20 and 2020-21 (projected), the predicted debt-GDP ratio on the combined account is likely to be close to $81 \%$ with centre's debt at $51.0 \%$ of GDP and states' at $29.6 \%$ of GDP. Thus, the combined debt-GDP ratio of the central and state governments is likely to exceed the targeted level of $60 \%$ by more than $20 \%$ points at the end of the current fiscal year. We may note that the World Bank (July 2020) has projected in their baseline scenario, that the general government debt in India would increase to $87.5 \%$ of GDP at the end of $2021-22$ and to $89.2 \%$ at the end of $2022-23$. This implies a slippage of nearly $30 \%$ points from the FRBMA target of $60 \%$, if we go by the World Bank estimate for 2022-23. 
Table 1: Estimated debt-GDP ratio: centre, states and combined

\begin{tabular}{|c|c|c|c|c|}
\hline Years & $f_{t}$ & $b_{t}$ & $b_{t}-b_{t-1}$ & $g_{t}$ \\
\hline \multicolumn{5}{|c|}{ Combined Centre and States } \\
\hline $2017-18$ & 5.9 & 69.8 & & 11.1 \\
\hline 2018-19 & 5.5 & 68.4 & -1.4 & 11.0 \\
\hline 2019-20 & 7.4 & 71.2 & 2.8 & 7.2 \\
\hline 2020-21 (projected) & 11.5 & 80.6 & 9.4 & 3.0 \\
\hline \multicolumn{5}{|l|}{ Centre } \\
\hline 2017-18 & 3.5 & 44.7 & & 11.1 \\
\hline 2018-19 & 3.4 & 43.7 & -1.0 & 11.0 \\
\hline 2019-20 & 4.6 & 45.4 & 1.7 & 7.2 \\
\hline 2020-21 (projected) & 7.0 & 51.0 & 5.7 & 3.0 \\
\hline \multicolumn{5}{|l|}{ States } \\
\hline 2017-18 & 2.4 & 25.1 & & 11.1 \\
\hline 2018-19 & 2.1 & 24.7 & -0.4 & 11.0 \\
\hline 2019-20 & 2.8 & 25.9 & 1.1 & 7.2 \\
\hline $2020-21$ (projected) & 4.5 & 29.6 & 3.7 & 3.0 \\
\hline
\end{tabular}

Source: IPFS, Union Budgets, RBI FY20 Annual Report (released 25 August 2020)

Notes: (1) Initial debt to GDP ratio for FY18 has been sourced from the RBI and for subsequent years, debt-GDP ratios have been estimated using the fiscal deficit numbers from the Union Budget and the RBI; (2) the debt-GDP ratio in FY18 includes external debt evaluated at current exchange rates; (3)The projected debt-GDP ratios of the center excludes extra budgetary borrowing, (4) The Combined debt-to-GDP ratio and the center's debt to GDP ratio are net of inter-governmental transactions between the center and the state governments amounting to 5\% points of GDP due to the following components: (a) NSSF investment in State governments special securities (b) Loans and advances by the center to states and (c) State governments' investment in center's treasury bills.

\section{Infirmities in the fiscal policy framework}

The combined debt-GDP ratio is estimated to rise by nearly 3\% points in 2019-20 and 9\% points in 2020-21. This cumulated increase of nearly $12 \%$ points would render the 2018 amendment completely out of alignment. In fact, the 2018 FRBMA has a number of other infirmities as discussed below:

1. Elimination of revenue deficit target: Maintaining balance or surplus on revenue account is critical since it is linked to government sector dissavings ${ }^{\text {ii }}$. For realizing India's potential growth, it is critical to maximize the savings rate. One important instrument for this is to maintain government's revenue account in balance or in surplus. This was also the primary objective of centre's 2003 FRBMA. The objective of maintaining a revenue account balance has been given up in the 2018 amendment to the Centre's FRBMA.

2. Inconsistent targets for debt and deficit for centre and states: It can be seen that maintaining a fiscal deficit target of 3\% of GDP for both centre and states is inconsistent with targeting debt-GDP ratio at $40 \%$ for centre and $20 \%$ for states. Simulations indicate that they should both be equal if 
the fiscal deficit targets are equal. Charts 3 and 4 show that they would converge to an equal level if fiscal deficit to GDP ratios are equal and the nominal growth rate is common. In this example, the nominal annual growth rate is assumed to be $12 \%$ and fiscal deficit is assumed at $3 \%$ of GDP each for the centre and states.

\section{Chart 3: Centre's Debt-GDP ratio}

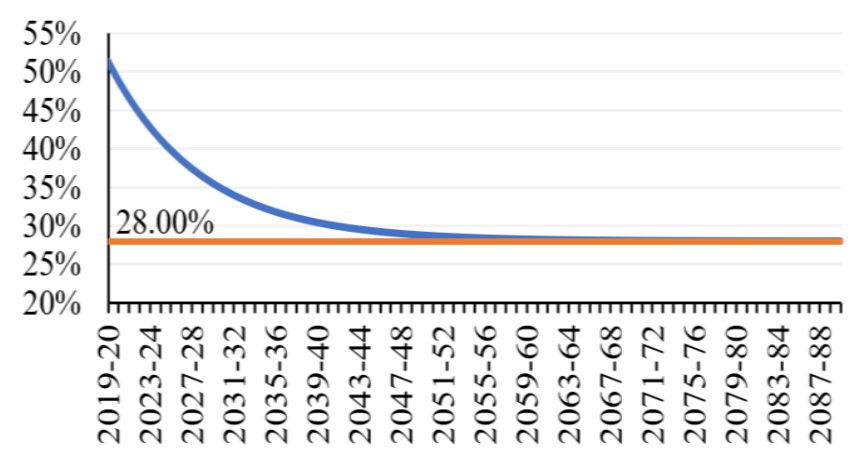

\section{Chart 4: States Debt-GDP ratio}

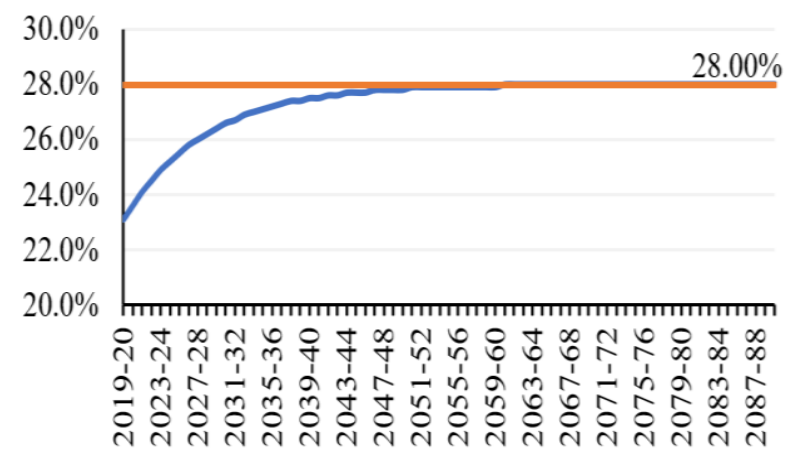

Source: RBI, MOSPI, and author's estimates; Note: Initial debt to GDP ratio for 2019-20 for the center was taken at 51.4\% (RE). Debt-GDP ratio for all states was taken at $23.1 \%$ (RE)

3. Inadequate countercyclical clauses: Centre's 2018 FRBMA has a provision for countercyclical measures. It provides for five conditions in which a departure from the operational fiscal deficit target of $3 \%$ of GDP can be made. These conditions relate to: (a) national security, (b) act of war, (c) national calamity, (d) collapse of agriculture severely affecting farm output and incomes and (e) structural reforms in the economy with unanticipated fiscal implications. The Act provides that if, as a result of one or more of the above conditions, there is a "...decline in real output growth of a quarter by at least 3\% points below its average of the previous four quarters...", then fiscal deficit limit may be increased but this increase "shall not exceed one half percent of the gross domestic product in a year". The COVID-19 pandemic may be classified as a national calamity under clause (c) above. However, the real GDP growth had started declining in the pre-pandemic quarters. In fact, it declined from a peak of $8.2 \%$ in the fourth quarter of $2017-18$ for eight successive quarters, with one exception in the fourth quarter of $2018-19$, to $3.1 \%$ in the fourth quarter of 2019-20. Yet this rule of a departure of $0.5 \%$ points of GDP could not be invoked. Its conditions proved to be too impractical to capture the evolving situation. When it was invoked in 2019-20, the cited reason was 'structural reforms' and the magnitude of actual departure became much larger than $0.5 \%$ points 
of $\mathrm{GDP}^{3}$. Further, in a pandemic kind of situation also, the magnitude of permitted departure proved to be too inadequate.

\section{Monetary policy framework}

Monetary policy in India has evolved from a multiple indicator approach and a focus on WPI inflation to a regime of flexible inflation targeting and focus on CPI inflation. In February 2015, a Monetary Policy Framework was agreed upon between the Government of India and the RBI. As per the framework, the RBI was mandated to target a CPI inflation rate below $6 \%$ by January 2016. CPI inflation target for 2016-17 and beyond was set at $4 \%$ with a tolerance range of $+/-2 \%$, implying an overall CPI inflation range of $2 \%$ to $6 \%$. This target is to be reviewed once every five years. It is due for a review in March 2021. In order to implement this framework, a Monetary Policy Committee (MPC) was established in September 2016 by amending the RBI Act. The MPC consists of six members, three from the RBI, and three outside experts/government officials. The Governor is the exofficio Chairperson. The RBI has been mandated to publish a Monetary Policy Report every six months explaining the sources of inflation and forecasts of inflation for the next 6 to 18 months. According to the Monetary Policy Framework, the RBI would fail to meet the target if the rate of inflation is more than $6 \%$ or less than $2 \%$ for three successive quarters. Further in case of failure, the RBI is required to submit a report to the Central government detailing a) the reasons for failure, b) remedial actions to be taken and c) estimate of time period within which the target would be achieved.

Since the adoption of CPI inflation target of 4\% in 2016, the average inflation rate during April 2016 to March 2020 has been 4.1\%. (Chart 5). We note that the annual IPD-based inflation was below the CPI inflation by a margin of $1.2 \%$ during $2014-15$ to $2019-20$ on average. If we consider this difference from 2015-16 onwards, it has come down to $0.9 \%$ points. It may be noted that the relationship between core CPI inflation and IPD-based inflation is more stable since most of the volatility in CPI inflation is caused by variations in food and fuel prices which are excluded from core CPI inflation and does not

\footnotetext{
${ }^{3}$ Centre's fiscal deficit was budgeted at 3.5\% of GDP for 2019-20. The actual fiscal deficit relative to GDP was at $4.6 \%$.
} 
have much influence on IPD-based inflation. IPD-based inflation has an important bearing on nominal GDP growth (Chart 6).

\section{Chart 5: CPI inflation}

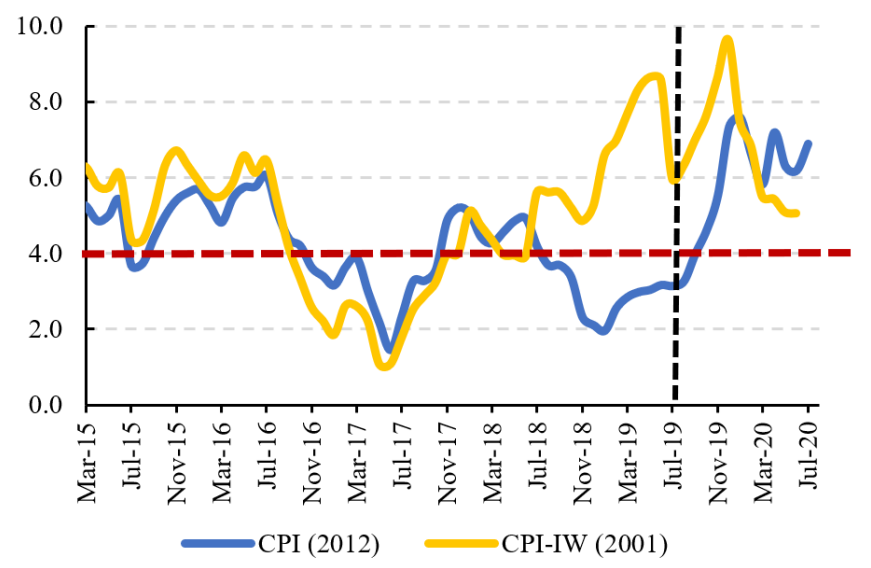

Chart 6: IPD based inflation and nominal GDP growth

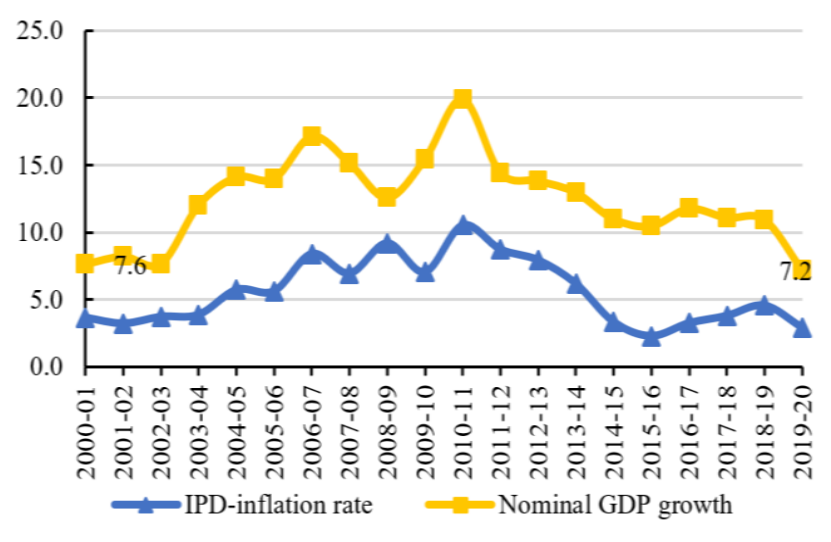

Source (basic data): MOSPI

\section{Policy anchor: relative merits of alternative inflation measures}

There are three main measures of inflation available in India namely CPI, WPI and the implicit GDP deflator. The GDP deflator is available only at quarterly and annual frequencies. A new CPI series became available in January 2011. Historically, the WPI has been maintained on a consistent basis for the longest period of time in India but has been considered inadequate for policy guidance since it does not include services and does not reflect prices that consumers actually pay. For policy guidance, many countries use CPI inflation rate as an anchor. Sometimes, using core CPI inflation which excludes food and fuel prices is considered to be better since these two are determined largely by exogenous factors. Even if CPI is chosen as the policy anchor for inflation, it is important to keep in mind its relationship with the IPD-based inflation as this has a bearing on tax revenue growth and therefore on the fiscal side of the economy.

\section{Reviewing growth experience in India: real and nominal}

One key macro policy objective is to ensure that the actual growth in the economy remains close to its potential growth (Rangarajan and Srivastava, 2017). While there are a number of methods for 
measuring potential growth, it is often captured by estimating the trend growth rate over a longer period of time which is estimated in a manner such that cyclical movements are ironed out. For this purpose, we consider the 2011-12 base GDP series.

\section{Chart 7: Real GDP growth: actual and trend}

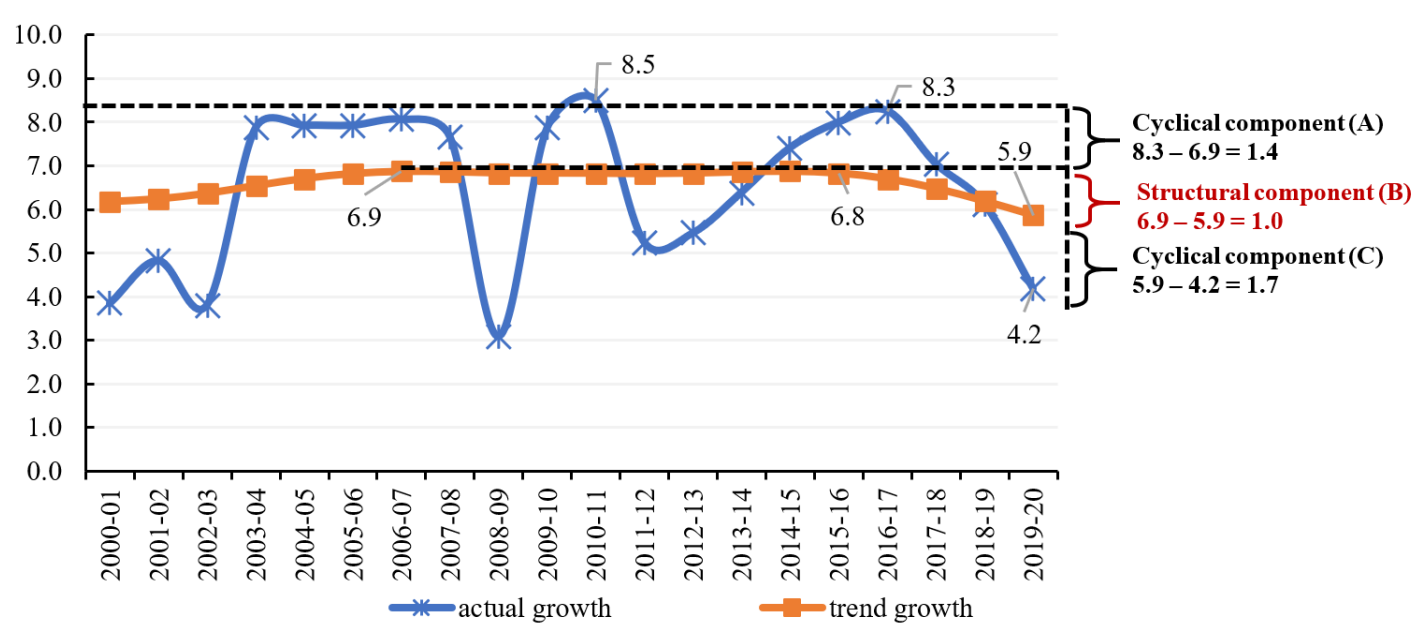

Source: MOSPI; Note: the trend growth was estimated using Hodrick-Prescott filter using a lambda value of 50

Chart 7 shows that while actual growth peaked at $8.3 \%$ in $2016-17$, the trend growth rate remained close to $7 \%$ over a longish period ranging from 2006-07 to 2015-16. In 2019-20, the difference between actual growth and the most recent peak growth amounts to $4.1 \%$ points. This fall is due to structural as well as cyclical factors. The cyclical factors account for $3.1 \%$ points whereas the structural component accounts for nearly $1 \%$ point of GDP. It is the responsibility of the macro policy makers to ensure that both the cyclical and structural gaps are minimized. The structural problem has effectively remained unattended. This becomes apparent from the persistent decline in India's saving and investment rates since 2010-11 (EY Economy Watch, September 2019). The structural problem was overlaid by a cyclical problem of deficient demand in the more recent years particularly 2019-20.

\section{Analyzing movement of IPD-based inflation}

A link is provided between the monetary policy framework and the fiscal policy framework through the profile of IPD-based inflation. The monetary authorities manage the CPI inflation and by implication also manage the IPD-based inflation. This has a bearing on GDP in nominal terms which determines tax revenue growth, which in turn critically affects the fiscal space. If tax revenue growth falls unduly, 
it will affect the public sector saving rate by adversely affecting government's revenue deficit. It will also force the public authorities to borrow more and thereby affect the fiscal deficit. Thus, fiscal and monetary policy decisions must be coordinated for optimum results. This coordination is discussed in the next section.

Chart 8 shows that the deflator-based inflation fell on trend basis from a peak of $7.6 \%$ in $2009-10$ to $2.8 \%$ in $2019-20$. Nominal GDP growth also fell on trend basis from a peak of $14.9 \%$ in $2010-11$ to $8.8 \%$ in $2019-20$. The actual nominal GDP growth fell to 7.2\% in 2019-20 (not shown here). Centre's gross tax revenue (GTR) growth also fell on trend basis, from $16.8 \%$ in $2007-08$ to $5.8 \%$ in $2019-20$ (Chart 9). In actual terms, there was in fact, a contraction in centre's gross tax revenues of (-)3.4\% in 2019-20.

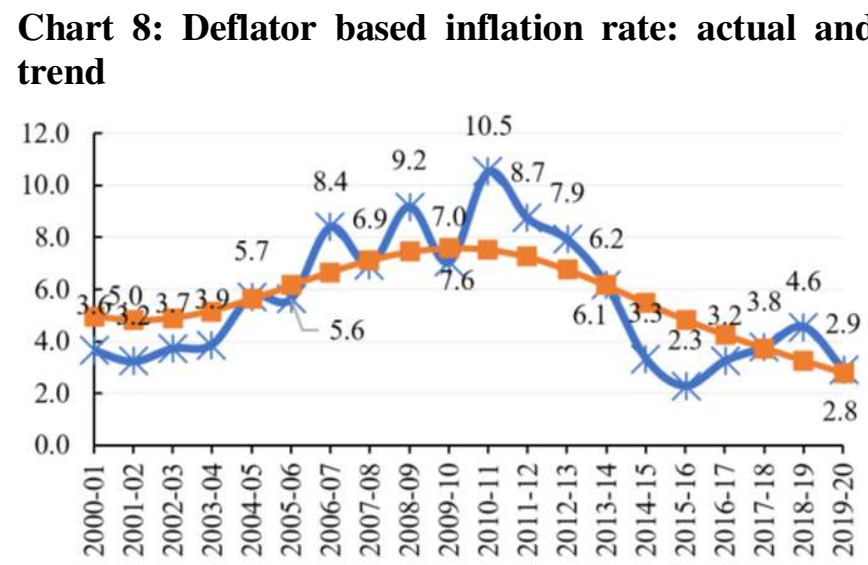

$-m$ actual
- trend
Chart 9: centre's GTR growth: trend and actual

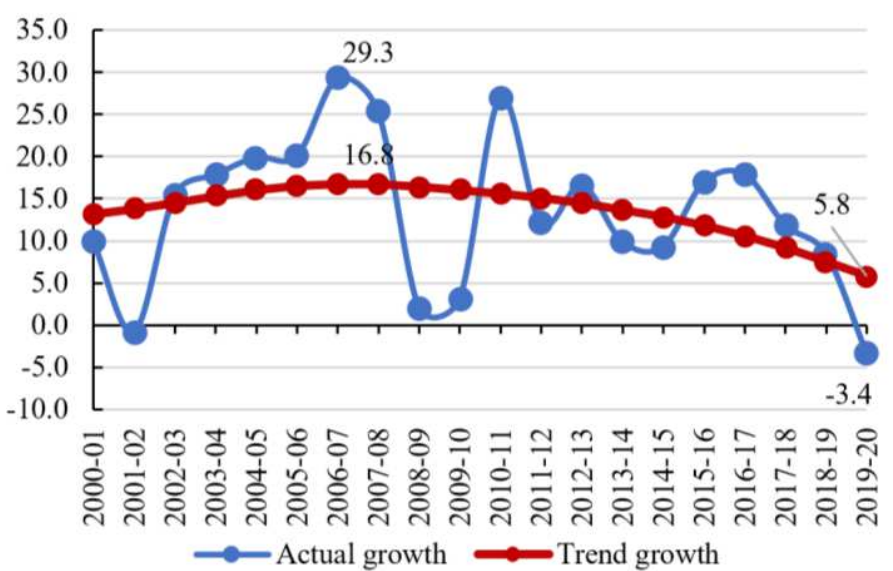

Source: MOSPI

Notes: the trend growth was estimated using Hodrick-Prescott filter using a lambda value of 50

This review indicates two important deficiencies in the monetary policy framework in the current Indian context. First, there is no emphasis on the growth objective for the MPC to consider. Second, the CPI inflation target of $4 \%$ on average implies an IPD-based inflation of $2.5-3 \%$. This is too low and inconsistent with the fiscal policy framework which assumes a nominal GDP growth of $11-12 \%$ as discussed in Section 5. 


\section{Issues of coordination between monetary and fiscal policy frameworks}

There are notable inconsistencies between implicit growth and inflation targets in major macro policy decisions which were taken roughly around the same time. In the case of fiscal policy decisions, two implicit assumptions regarding nominal GDP growth are important. First, with respect to GST which was implemented on 1 July 2017, the states were guaranteed a growth of $14 \%$ in nominal terms in their share of GST revenues. This guarantee was implemented through the mechanism of the compensation cess. A 14\% growth in GST revenues assumes a combination of GST buoyancy and nominal GDP growth. The higher the buoyancy, the lower would be the implicit assumption of nominal GDP growth. It would be reasonable to assume that at the time of transition to a revenue neutral GST, a buoyancy higher than 1.2 would have been unreasonable. In fact, the actual buoyancy turned out to be much lower. A buoyancy of 1.2 for the component of GST attributable to states (SGST + states' share in IGST) implies a nominal GDP growth of $11.7 \%$ per annum. In the year in which GST was introduced, the Union Budget had assumed a nominal GDP growth of 11.75\% (Union Budget 2017-18). According to the minutes of the 3rd GST Council Meeting held on 18-19 October 2016, most state ministers had argued for a $14 \%$ growth over the base year GST revenue, considering a nominal GDP growth of $12 \%$ or above.

Second, for stabilizing the combined debt to GDP ratio at $60 \%$ with a $6 \%$ combined fiscal deficit-GDP target as per 2018 amendment to the centre's FRBMA, the implicit nominal GDP growth rate works out to be nearly $11 \%$ (see Table 2). In fact, the FRBM Review Committee mentioned a target growth rate of $11.5 \%$. These growth assumptions turned out to be much higher than the nominal GDP growth outcome driven by the MPF. As discussed earlier, the MPF targeted a CPI inflation at 4\%. We note that the IPD based inflation during 2014-15 to $2019-20$ was below the CPI inflation by $1.2 \%$ points on average. This implies that a CPI inflation target of $4 \%$ was associated with an IPD based inflation of 2.8\% during 2014-15 to 2019-20. The difference between CPI inflation and IPD-based inflation increased to $1.9 \%$ points in 2019-20. Combining the average IPD based inflation at $2.8 \%$ with the average real GDP growth at 6.8\% during 2014-15 to 2019-20, the resultant nominal GDP growth comes 
out to be $9.8 \%$. This outcome emerging from the MPF is well-below that emerging from the fiscal policy framework which ranges from 11-12\%.

Thus, there is a built-in inconsistency between the two macro policy frameworks. The outcome of this independent pursuit of two macro policy frameworks was that the monetary policy pursuits kept driving the nominal GDP growth down, thereby reducing government's fiscal space which is dependent on tax buoyancy and nominal GDP growth. This led to persistent upward pressures on the fiscal deficit thereby making the central government miss its target of 3\% year after year. The GST revenues also fell well short of the implicit growth of $14 \%$. There is thus a clear need for removing the inconsistency between the two macro policy frameworks.

\section{Modifying macro policy frameworks and tackling coordination issues}

\section{Fiscal policy framework}

The centre's FRBMA has been thrown out of gear because at the end of 2020-21, the policy anchor namely, the combined debt-GDP ratio is likely to be close to $81 \%$, more than $20 \%$ points higher than its target value of $60 \%$. Given the history of correction in the debt-GDP ratio, bringing it down from $81 \%$ to $60 \%$ may prove to be extremely unrealistic. The average annual rate of change in the combined debt-GDP ratio over the period from $1990-91$ to $2019-20$ is close to $0(0.030 \%$ points $)$ with some patches where inter-year variations were relatively larger. This historical experience shows that achieving a reduction of more than $20 \%$ points is highly unlikely. It may be more appropriate to recast the FRBMA particularly in view of the need for the central government to play a more active role in uplifting investment and growth.

There is a case to consider asymmetric debt-GDP targets for the centre vis-à-vis. the states. In fact, the central government may be given a higher target in view of (a) its higher current debt-GDP levels, (b) its relatively more important macro stabilization role, and (c) its pivotal role in building defence and non-defence infrastructure under the current circumstances faced by India. 


\section{Deriving sustainable debt and deficit combinations relative to GDP with respect to simulated growth rates}

Sustainable levels of debt and fiscal deficit $\left(b^{*}\right.$ and $\left.f^{*}\right)$ can be derived as pairs with respect to a given level of nominal GDP growth rate $(g)$. This relationship is given in equation (1) below. For detailed derivation, see Rangarajan and Srivastava (2005). Here, by sustainability, it is indicated that if a given target nominal growth rate is achieved, and fiscal deficit is maintained at the level given in equation (1) year after year, debt can be maintained at a stable level, year after year. In this sense, debt-GDP ratio can be considered as sustainable.

$b^{*}=f^{*} \frac{(1+g)}{g}$

In Table 2, we have considered nominal growth levels for the Indian economy ranging from $10 \%$ to $13.5 \%$. These growth rates are combined with alternate values of fiscal deficit to GDP ratio to derive the related value of debt-GDP ratio at which it would emerge to be stable. The fiscal deficit relative to GDP ranges from $2 \%$ to $8 \%$. These values can cover feasible ranges of fiscal deficit to GDP ratio for the central government, for the aggregate of state governments, and for their combined account. The relevant range for growth rate may be considered as $11-12 \%$. This is common for central as well as state governments. Thus, it is indicated that a combination of $3 \%$ of fiscal deficit-GDP and $11 \%$ of nominal GDP growth will result in a stable debt-GDP ratio of 30.3\%. This is so both for the central as well as for aggregate of state governments. At fiscal deficit to GDP ratio of 4\%, the stable debt GDP ratio will emerge at $40.4 \%$ if it is combined with maintaining a nominal growth rate of $11 \%$ year after year. If we consider the combined account of central and state governments and maintain fiscal deficit at $6 \%$ of GDP, the stable debt-GDP ratio would be $60.5 \%$. If the combined fiscal deficit to GDP ratio is raised to $7 \%$, debt-GDP ratio can be stabilized at $70.6 \%$. This simulation table can be used to inform the choice of determining a suitable combination for nominal growth rate, fiscal deficit to GDP ratio, and debtGDP ratio individually for central and state governments as well as on their combined account. 
Table 2: Sustainable combinations of debt-GDP and fiscal deficit to GDP ratios: Centre, States and Combined

\begin{tabular}{|c|c|c|c|c|c|c|c|c|}
\hline $\mathbf{f} / \mathbf{g}$ & 0.10 & 0.105 & $\mathbf{0 . 1 1 0}$ & 0.115 & 0.120 & 0.125 & 0.130 & 0.135 \\
\hline 0.020 & $22.0 \%$ & $21.0 \%$ & $20.2 \%$ & $19.4 \%$ & $18.7 \%$ & $18.0 \%$ & $17.4 \%$ & $16.8 \%$ \\
\hline 0.025 & $27.5 \%$ & $26.3 \%$ & $25.2 \%$ & $24.2 \%$ & $23.3 \%$ & $22.5 \%$ & $21.7 \%$ & $21.0 \%$ \\
\hline $\mathbf{0 . 0 3 0}$ & $33.0 \%$ & $31.6 \%$ & $\mathbf{3 0 . 3 \%}$ & $29.1 \%$ & $28.0 \%$ & $27.0 \%$ & $26.1 \%$ & $25.2 \%$ \\
\hline 0.035 & $38.5 \%$ & $36.8 \%$ & $35.3 \%$ & $33.9 \%$ & $32.7 \%$ & $31.5 \%$ & $30.4 \%$ & $29.4 \%$ \\
\hline $\mathbf{0 . 0 4 0}$ & $44.0 \%$ & $42.1 \%$ & $\mathbf{4 0 . 4 \%}$ & $38.8 \%$ & $37.3 \%$ & $36.0 \%$ & $34.8 \%$ & $33.6 \%$ \\
\hline 0.045 & $49.5 \%$ & $47.4 \%$ & $45.4 \%$ & $43.6 \%$ & $42.0 \%$ & $40.5 \%$ & $39.1 \%$ & $37.8 \%$ \\
\hline 0.050 & $55.0 \%$ & $52.6 \%$ & $50.5 \%$ & $48.5 \%$ & $46.7 \%$ & $45.0 \%$ & $43.5 \%$ & $42.0 \%$ \\
\hline 0.055 & $60.5 \%$ & $57.9 \%$ & $55.5 \%$ & $53.3 \%$ & $51.3 \%$ & $49.5 \%$ & $47.8 \%$ & $46.2 \%$ \\
\hline $\mathbf{0 . 0 6 0}$ & $66.0 \%$ & $63.1 \%$ & $\mathbf{6 0 . 5 \%}$ & $58.2 \%$ & $56.0 \%$ & $54.0 \%$ & $52.2 \%$ & $50.4 \%$ \\
\hline 0.065 & $71.5 \%$ & $68.4 \%$ & $65.6 \%$ & $63.0 \%$ & $60.7 \%$ & $58.5 \%$ & $56.5 \%$ & $54.6 \%$ \\
\hline $\mathbf{0 . 0 7 0}$ & $77.0 \%$ & $73.7 \%$ & $\mathbf{7 0 . 6 \%}$ & $67.9 \%$ & $65.3 \%$ & $63.0 \%$ & $60.8 \%$ & $58.9 \%$ \\
\hline 0.075 & $82.5 \%$ & $78.9 \%$ & $75.7 \%$ & $72.7 \%$ & $70.0 \%$ & $67.5 \%$ & $65.2 \%$ & $63.1 \%$ \\
\hline 0.080 & $88.0 \%$ & $84.2 \%$ & $80.7 \%$ & $77.6 \%$ & $74.7 \%$ & $72.0 \%$ & $69.5 \%$ & $67.3 \%$ \\
\hline
\end{tabular}

Source: Author's estimates

It would be useful to work out the adjustment path to reach this level from the expected peak level of debt-GDP ratio at the end of 2022-23. Another important change that is required in centre's FRBMA relates to the strategy for dealing with countercyclical interventions.

\section{Distinguishing between agricultural and non-agricultural cycles}

In this section, we consider the desirability of developing countercyclical policy instruments which are different for dealing with agricultural vis-à-vis. non-agricultural cycles.

In spite of cumulated investment in irrigation across India, Indian agriculture remains heavily dependent on monsoon and therefore, the cycles that get generated linked to the cyclicality of the rainfall relative to its long period average. This cyclicality is regular in terms of its periodicity, broadly comparable in terms of the related cyclical amplitudes, and its impact on agricultural output and incomes as well as the overall economy. 
Chart 10: Real agricultural growth: actual and trend (\%)

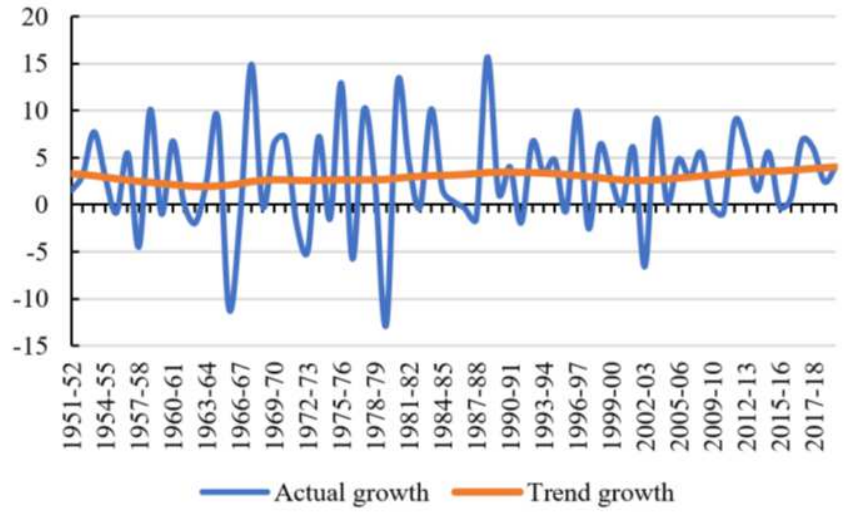

Chart 11: Cyclicality in agricultural growth: deviation of actual growth from trend growth $(\%$ points)

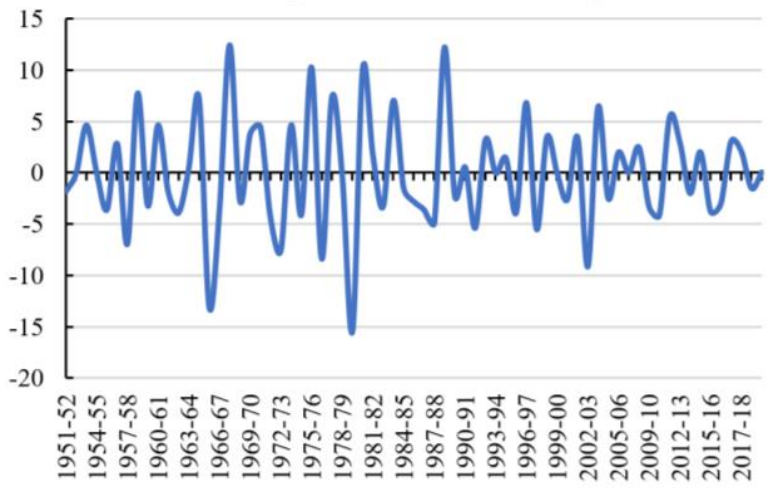

Source (basic data): MOSPI

Charts 10 and 11 indicate that the periodicity of real growth in agricultural output (GVA) in India over the last 70 years is close to 3 years. We also notice that the amplitude of agricultural cycles has come down over time. In comparison, for non-agricultural output (GVA) growth, the average periodicity over the same period is close to 6 years (not shown here).

There are two major countercyclical instruments which can be embedded in the FRBMA. One is to establish a stabilization fund ${ }^{\mathrm{iii}}$ from which governments may withdraw in slowdowns while replenishing the fund in expansionary phases. The other instrument is to allow a flexibility in the fiscal deficit limit in relation to its target value, borrowing more than average in slowdowns and less than average in expansionary phases. It may be useful to utilize both instruments in India's case. A stabilization fundbased approach may be effective for tackling agricultural cycles. Further, since agriculture is a state subject and often agricultural droughts tend to be state-specific, states may be given the facility to draw from the fund which should be established and managed by the central government so that discipline is maintained. For the non-agricultural cycle, a flexibility of about $1 \%$ point of GDP in the fiscal deficit may be provided for the central government. In macro stabilization literature, countercyclical policy is the main responsibility of the central government. However, these instruments are meant for regular and periodic agricultural and non-agricultural cycles. This framework would break down in the case of structural breaks such as a pandemic or a war. In these exceptional circumstances, it may be better to 
have an institutional framework which can devise appropriate methods for dealing with such situations requiring coordination between central and state governments as well as fiscal and monetary authorities.

\section{Ensuring consistency with saving investment profiles}

For the fiscal framework, the internally consistent target real GDP growth rate is set at its potential level of $8 \%$. This would require an investment of about $36 \%$ of GDP, which may be financed by domestic savings of $33.5 \%$ of GDP and net capital inflow of $2.5 \%$ of GDP which is consistent with a corresponding sustainable level of current account deficit (CAD). The domestic saving rate of 33.5\% requires uplifting the current rate of about $29 \%$ by more than $4 \%$ points. This is to be brought about mainly by eliminating revenue deficits of the central and state governments and by marginally uplifting savings of household and private corporate sectors together by margins of $0.5-1 \%$ point of GDP.

\section{Modifying Monetary policy framework}

The monetary policy framework is due for a review every five years. Thus, it should be reviewed in March 2021. In view of the earlier discussion, the following changes in the monetary policy framework may be considered:

1. The RBI may continue with CPI inflation as the target variable.

2. The average targeted CPI inflation rate may be kept at $5 \%$ with a tolerance range of $+/-2 \%$, so that the IPD based inflation is targeted at $4 \%$ on average.

3. The monetary authority may keep in mind an annual real GDP potential growth target of $8 \%$ and a nominal GDP growth target of $11-12 \%$. The monetary authority should ensure this in coordination with the fiscal authorities. For this coordination, an institution like a Macro Policy Coordination Council (or Fiscal Council) may prove to be quite effective.

\section{Coordination issues: role of Macro Policy Coordination Council}

There are important coordination issues in managing fiscal and monetary policy frameworks. This is a highly specialized task requiring periodic monitoring, and informing the policymakers both on the monetary and fiscal sides, of the expected implications of their actions. In fact, coordination is needed 
between the central government, indvidual state governments and UTs with legislatures, and the MPC. Such a task is best attended to by an institutional innovation such as the setting up of a Macro Policy Coordination Council (or a Fiscal Council). Many countries across the world have established autonomous Fiscal Councils. Such a Council or similar bodies has also been recommended by a number of recent Finance Commissions as also by the FRBM Review Committee in 2017. The Fiscal Statistics Committee of the National Statistical Commission had also examined this issue and endorsed the need for instituting a Fiscal Council in India which can play a role as (a) co-ordinator of macro-stabilization policies, (b) fiscal data coordinator, (c) fiscal data analyst, (d) fiscal consolidation path monitor, (e) forecaster of fiscal aggregates, and (f) fiscal policy advisor.

The proposed Macro Policy Coordination Council may keep the following targets as part of its objective functions: (1) potential real GDP growth of $8 \%$, (2) CPI inflation of $5 \%$ with a flexibility of $+/-2 \%$ or equivalently, an IPD based inflation of $4 \%$ with a flexibility of $+/-2 \%$, (3) nominal GDP growth target in the range of $11-12 \%$, and (4) combined debt-GDP target at $70 \%$ with $40 \%$ for the centre and $30 \%$ for the states. Correspondingly, the fiscal deficit targets should be $7 \%$ for the combined government with $4 \%$ for the centre and $3 \%$ for the states.

\section{Summary and concluding observations}

We have reviewed India's monetary and fiscal policy frameworks which have guided policymaking during the last five years. We have noted that there are certain infirmities and inconsistencies in these policy frameworks. Further, there has been a lack of coordination between the pursuits of fiscal and monetary authorities to ensure desirable growth and inflation outcomes. In fact, there is an inconsistency in their implicit assumptions. In view of these observations, it may be useful to recast these frameworks for which the following may be considered.

\section{a. Fiscal framework}

1. The 2018 version of FRBMA should be re-amended. 
2. The new FRBMA should bring back revenue account balance as a key target for both central and state governments.

3. There is a case to consider the need for introducing asymmetric targets for fiscal deficit and correspondingly for debt relative to GDP for the central government vis-à-vis. the state governments. Centre's fiscal deficit and debt may be kept at somewhat higher levels in the current circumstances of the Indian economy given the macro stabilizing role that the centre undertakes and the need to build infrastructure in the next five years or so. We may consider a combination of $40 \%$ of debt-GDP ratio and $4 \%$ of fiscal deficit to GDP ratio for the centre and $30 \%$ of debtGDP ratio and 3\% of fiscal deficit-GDP ratio for the states considered together (Table 3). These are stable combinations at a nominal growth rate of $11 \%$. Together, the debt-GDP ratio target can be increased to $70 \%$. It may be noted that for the last 30 years, the combined debt-GDP ratio of the central and state governments in India has remained close to $70 \%$ with some patches where inter-year variations were relatively larger.

4. The combined fiscal deficit to GDP ratio at $7 \%$ can be financed by a surplus in the household sector savings rate of an equal amount. The net borrowing requirement of the non-government public sector and the private corporate sector taken together, of 2.5-3\% of GDP can then be met by net capital inflows. As revenue deficit of central and state governments is progressively reduced to zero, this would become quite feasible.

5. This level of fiscal deficit for the government can be sustained at a suitable level of savinginvestment combination consistent with the potential growth rate of $8 \%$. At an incremental capital output ratio (ICOR) of 4.5 , an investment rate of $36 \%$ would be required to generate this growth. Considering $2.5 \%$ of GDP as sustainable level of net capital inflows, a domestic saving rate of $33.5 \%$ is required. This can be obtained by combining (a) household sector saving at $19 \%$ with a financial saving component of about $8 \%$, (b) private corporate saving of $10.5 \%$, and (c) public sector saving of $4 \%$. These levels are only marginally above those achieved by household and private corporate sectors in recent years. The main improvement is to be brought about in public sector saving for which keeping government's revenue account in balance is necessary. 
6. State governments should be given a specific macro stabilization role particularly for agricultural cycles which may be handled by establishing an Agricultural Cycle Stabilization Fund (ACSF).

7. Non-agricultural cycles should be handled by a rule-based flexibility of $1 \%$ point of GDP in centre's fiscal deficit wherein there should be a mechanism for ensuring that departures of fiscal deficit from its average target are followed symmetrically in cyclical upturns and downturns so that the debt-GDP ratio remains sustainable and stable.

\section{b. Monetary framework}

1. The monetary policy framework of 2015 should be amended.

2. The MPC should keep in mind, a growth objective although it is to be monitored by the suggested Macro Policy Coordination Council ${ }^{4}$.

3. The target variable may continue to be CPI.

4. The target CPI inflation rate may be kept at $5 \%$ on average with a tolerance range of $+/-2 \%$ points. This would be consistent with an IPD based inflation rate of $4 \%$ on average (Table 4).

\section{c. Institutional framework}

1. A Macro Policy Coordination Council should be established. It may serve a number of objectives but the most important would be to provide a framework in which monetary and fiscal policy decisions are coordinated. It may also deal with instances of structural breaks caused by extraordinary exogenous events such as a pandemic or a war. Growth and inflation targets should be defined for both of these frameworks in a mutually consistent way.

2. The Macro Policy Coordination Council may aim at a potential real GDP growth rate of $8 \%$, a nominal GDP growth in the range of $11-12 \%$, and CPI based inflation of $5 \%{ }^{5}$ with a flexibility of $+/-2 \%$ or equivalently, an IPD based inflation of $4 \%$ with a flexibility of $+/-2 \%$. The combined debt-GDP target should be $70 \%$ with $40 \%$ for the centre and $30 \%$ for the states.

\footnotetext{
${ }^{4}$ In fact, the amended RBI Act of 1934 provides that the primary objective of monetary policy is to maintain price stability while keeping in mind the objective of growth

${ }^{5}$ There has been a discussion around determining a suitable threshold level of inflation for India which may be close to $5 \%$. For example see Rangarajan (2012), Mohanty, Chakraborty, et. al. (2011), Singh, P. (2010), and Pattanaik, S., \& Nadhanael, G. V. (2011).
} 
Correspondingly, the fiscal deficit targets should be $7 \%$ for the combined government with $4 \%$

for the centre and $3 \%$ for states.

These suggestions are summarized in Tables 3 and 4 below.

Table 3: FRBMA targets: present and proposed

relative to GDP at current market prices

\begin{tabular}{|l|c|c|l|c|c|l|}
\hline \multirow{2}{*}{$\begin{array}{l}\text { Tier of } \\
\text { government }\end{array}$} & \multicolumn{3}{|c|}{ Existing FRBM } & \multicolumn{3}{c|}{ Proposed FRBM } \\
\cline { 2 - 7 } & Debt & Fiscal deficit & Revenue deficit & Debt & Fiscal deficit & \multicolumn{1}{|c|}{ Revenue deficit } \\
\hline Centre & $40 \%$ & $3 \%$ & Not specified & $40 \%$ & $\mathbf{4 \%}$ & $\begin{array}{l}\text { Balance or } \\
\text { surplus }\end{array}$ \\
\hline State & $20 \%$ & $3 \%$ & $\begin{array}{l}\text { Balance or } \\
\text { surplus }\end{array}$ & $\mathbf{3 0 \%}$ & $3 \%$ & Balance or surplus \\
\hline Combined & $60 \%$ & $6 \%$ & Not specified & $\mathbf{7 0 \%}$ & $\mathbf{7 \%}$ & $\begin{array}{l}\text { Balance or } \\
\text { surplus }\end{array}$ \\
\hline
\end{tabular}

Source (basic data): Centre's 2018 FRBMA

Note: Centre's debt is net of on-lending to states. It is to be evaluated at current exchange rates.

Table 4: MPF: present and proposed

\begin{tabular}{|c|c|c|c|c|c|c|}
\hline \multirow[b]{2}{*}{ Target } & \multicolumn{2}{|c|}{ Existing } & \multicolumn{2}{|c|}{ Proposed } & \multicolumn{2}{|c|}{ Proposed (equivalent) } \\
\hline & $\begin{array}{c}\text { Selected } \\
\text { index }\end{array}$ & Level & $\begin{array}{c}\text { Selected } \\
\text { index }\end{array}$ & Level & Selected index & Level \\
\hline Average & \multirow{3}{*}{ CPI } & $4 \%$ & \multirow{3}{*}{ CPI } & $5 \%$ & \multirow{3}{*}{ IPD } & $4 \%$ \\
\hline $\begin{array}{l}\text { Range } \\
\text { (lower) }\end{array}$ & & $2 \%$ & & $3 \%$ & & $2 \%$ \\
\hline $\begin{array}{l}\text { Range } \\
\text { (upper) }\end{array}$ & & $6 \%$ & & $7 \%$ & & $6 \%$ \\
\hline
\end{tabular}

Source (basic data): Monetary Policy Framework, 2015

\section{Concluding observations}

The economic impact of the COVID-19 pandemic and economic trends preceding it have highlighted certain infirmities and inconsistencies in India's macro policy frameworks as consisting of fiscal and monetary policy frameworks. These need to be recast and supplemented with an institutional framework such as the setting up of a Macro Policy Coordination Council which can coordinate between monetary and fiscal authorities. This is also needed considering India's contemporary economic challenges in the backdrop of the evolving global situation. In this paper, it is demonstrated that with marginal changes 
in the fiscal and monetary policy frameworks, India can aspire to achieve and sustain a real GDP growth of $8 \%$ while keeping CPI inflation close to $5 \%$. 


\section{References}

1. Akın, Ç., Carrasco, B., Mundle, S. and Gupta, A.S., (2017). Fiscal Responsibility and Budget Management Act in India: A Review and Recommendations for Reform.

2. Ashok Banerjee and Partha Ray. (28 July 2020). RBI's Hamletian dilemma. published in Business Standard; https://www.business-standard.com/article/opinion/rbi-s-hamletian-dilemma120072800025_1.html?1595882772. Accessed 29 July 2020.

3. Edge, R.M. and Gürkaynak, R.S. (2011). How useful are estimated DSGE model forecasts?. Available at SSRN 1810075.

4. Edge, R.M., Gürkaynak, R.S., Reis, R. and Sims, C.A., (2010) How useful are estimated DSGE model forecasts for central bankers?. Brookings Papers on Economic Activity, pp.209-259.

5. EY Economy Watch (August 2020 edition). https://www.ey.com/en_in/tax/economy-watch/is-ittime-to-recast-india-fiscal-and-monetary-policy-frameworks

6. EY Economy Watch (September 2019).https://assets.ey.com/content/dam/ey-sites/eycom/en in/topics/tax/economy-watch-september-2019.pdf. Accessed 05 August 2020.

7. FRBM Review Committee (2017). Responsible Growth: A Debt and Fiscal Framework for 21st Century India. FRBM Review Committee Report, 1 (Page 54).

8. Hendry, D.F. and Mizon, G.E. (2014). Why DSGEs crash during crises. VOX CEPR Policy Portal; https://voxeu.org/article/why-standard-macro-models-fail-crises. Accessed 13 August $\underline{2020 .}$.

9. IMF (July 2020). World Economic Outlook Update. 'A Crisis Like No Other, An Uncertain Recovery' 
10. Ministry of Finance, Government of India. Fiscal Responsibility and Budget Management Act, 2003 (Act No. 39 of 2003).

https://dea.gov.in/sites/default/files/FRBM\%20Act\%202003\%20and\%20FRBM\%20Rules\%2020

04.pdf. Accessed 18 August 2020.

11. Ministry of Statistics and Programme Implementation (MOSPI), National Statistical Office (NSO). Compilation of Consumer Price Index: A Technical Note.

http://www.mospi.gov.in/sites/default/files/press release/CPI\%20Technical\%20Note\%20on\%20I mputation.pdf. Accessed 20 August 2020.

12. Mohanty, D., Chakraborty, A. B., Das, A., \& John, J. (2011). Inflation Threshold in India: An Empirical Investigation. Reserve Bank of India working paper series, 18, 2-9.

13. Pattanaik, S., \& Nadhanael, G. V. (2011). Why persistent high inflation impedes growth? An empirical assessment of threshold level of inflation for India. RBI Working Paper Series No. 17.

14. Rangarajan (2012). Inflation at 5\% an acceptable threshold for India: Rangarajan. Published in The Hindu Business Line (28 December 2012);

https://www.thehindubusinessline.com/economy/inflation-at-5-an-acceptable-threshold-for-indiarangarajan/article20545706.ece1. Accessed 27 August 2020.

15. Rangarajan, C. and D. K. Srivastava (2005). Fiscal Deficits and Government Debt. Economic and Political Weekly, Vol. 40, Issue No. 27, 02 July, 2005

16. Rangarajan, C., and D. K. Srivastava (2017). Underlying Drivers of India’s Potential Growth. Economic \& Political Weekly 52.25-26 (2017): 69-77.

17. RBI Act (1934) (As amended by the Finance (No. 2) Act, 2019); Chapter III F [Clause 45ZA (1)]; https://rbidocs.rbi.org.in/rdocs/Publications/PDFs/RBIA1934170510.PDF. . Accessed 08 August 2020. 
18. RBI and Ministry of Finance (February 2015). Agreement on Monetary Policy Framework. Ministry of Finance, Government of India. https://finmin.nic.in/sites/default/files/MPFAgreement28022015.pdf . Accessed 13 August 2020.

19. Report of the Advisory Committee constituted by the RBI. Ways and Means Advances to State Governments. (October 2005).

20. Report of the Committee on Fiscal Statistics (September 2018) constituted by National Statistical Commission, Government of India; http://www.mospi.gov.in/sites/default/files/committee_reports/Report\%20of\%20the\%20Committ ee\%20on\%20Fiscal\%20Statistics.pdf. Accessed 12 August 2020.

21. Report of the Twelfth Finance Commission. https://fincomindia.nic.in/writereaddata/html_en_files/oldcommission_html/fcreport/Report_of_1 2th_Finance_Commission/12fcreng.pdf. Accessed 03 August 2020.

22. Report of the Working Group constituted by the RBI. State FRL: The next phase (November 2009).

23. Singh, P. (2010). Searching threshold inflation for India. Economics Bulletin, 30(4), 3209-3220.

24. Srivastava, D.K., Shanmugam, K.R. and Rao, C.B. (2012). A macro-fiscal modeling framework for forecasting and policy simulations. Madras School of Economics.

25. Stiglitz, J.E., (2018). Where modern macroeconomics went wrong. Oxford Review of Economic Policy, 34(1-2), pp.70-106.

26. The Hindu (2016). Can India grow at 8 to 9 per cent?. Article by C. Rangarajan. Published 14 May 2016. https://www.thehindu.com/opinion/lead/Can-India-grow-at-8-to-9-percent/article14317462.ece. Accessed 26 August 2020.

27. World Bank. (July 2020). India Development Update. 


\section{List of Abbreviations}

\begin{tabular}{|l|l|l|}
\hline S. No. & Abbreviation & \\
\hline 1 & ACSF & Agricultural Cycle Stabilization Fund \\
\hline 2 & COVID-19 & Coronavirus disease 2019 \\
\hline 3 & CAD & Current Account Deficit \\
\hline 4 & CPI & Consumer Price Index \\
\hline 5 & FC & Finance Commission \\
\hline 6 & FRBMA & Fiscal Responsibility and Budget Management Act \\
\hline 7 & FRL & Fiscal Responsibility Legislation \\
\hline 8 & GDP & Gross Domestic Product \\
\hline 9 & GSDP & Gross State Domestic Product \\
\hline 10 & GST & Goods and Services Tax \\
\hline 11 & GTR & Gross tax revenues \\
\hline 12 & GVA & Gross Value Added \\
\hline 13 & ICOR & Incremental Capital Output Ratio \\
\hline 14 & IGST & Integrated Goods and Services Tax \\
\hline 15 & IPD & Implicit Price Deflator \\
\hline 16 & MPF & Monetary Policy Framework \\
\hline 17 & MPC & Monetary Policy Committee \\
\hline 18 & RBI & Reserve Bank of India \\
\hline 19 & SGST & State Goods and Services Tax \\
\hline 20 & UT & Union Territory \\
\hline 21 & WPI & Wholesale Price Index \\
\hline
\end{tabular}




\section{Declarations}

\section{a. Availability of data and materials}

The datasets used and/or analyzed during the current study are available from the corresponding author on reasonable request.

\section{b. Competing interests}

The authors declare that they have no competing interests.

\section{c. Funding}

The authors received no financial support for the research, authorship and/or publication of this article.

\section{d. Authors' contributions}

1. DKS suggested the overall theme, the methodology for estimating debt-GDP ratios linked to levels of fiscal deficit and other determinants and brought out the coordination issues between India's monetary and fiscal policy frameworks including some inbuilt inconsistencies in their implicit assumptions. He provided recommendations for modifying these frameworks individually while keeping in mind mutual consistency and coordination issues.

2. MB reviewed India's growth experience in real and nominal terms and analyzed the structural and cyclical reasons underlying the fall in growth on trend basis as also a sharp fall in recent years. He also analyzed trends in India's combined debt relative to GDP over the last 30 years.

3. TK undertook a review of Monetary Policy Framework of 2015 and India's inflation experience before and after the constitution of Monetary Policy Committee. He also analyzed the savings investment profile of the Indian economy.

4. RT analyzed the evolution and key features of the current fiscal policy framework of centre and states in India, reviewed the cyclicality of agricultural and non-agricultural growth in India, and was a major contributor in writing the manuscript.

All authors reviewed and approved the final manuscript. 


\section{e. Acknowledgements}

Not applicable

i Paragraph 4.54 of the Report of the Twelfth Finance Commission
ii Paragraph 4.13 of the Report of the Twelfth Finance Commission
iii For detailed discussion, see Report of the Working Group on 'State FRL: The next phase' (November 2009). 


\section{Figures}

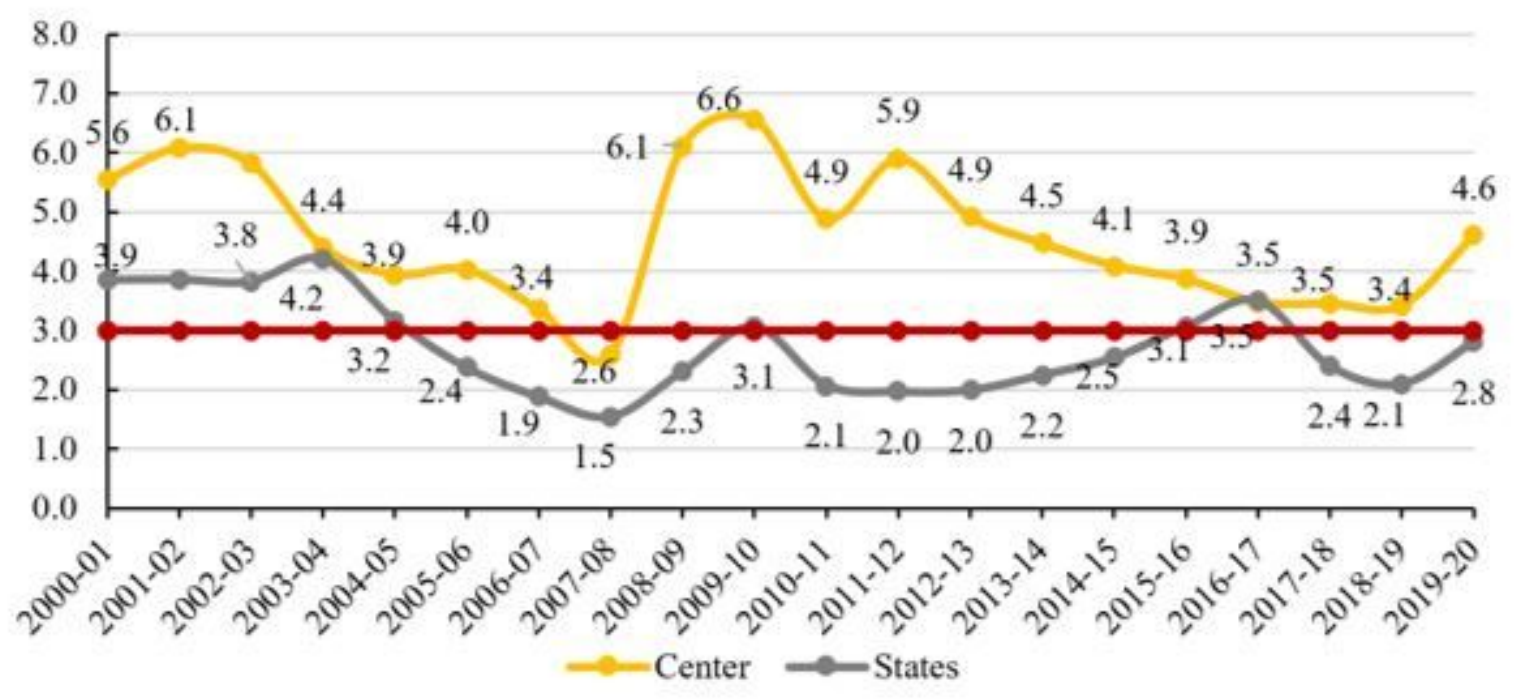

\section{Figure 1}

fiscal deficit (+) relative to GDP: Centre and states. Source (Basic Data): IPFS, CSO, RBI 2019-20 Annual Report (released 25 August 2020) Note: For states, data from 2016-17 onwards is sourced from the RBI where 2019-20 pertains to RE

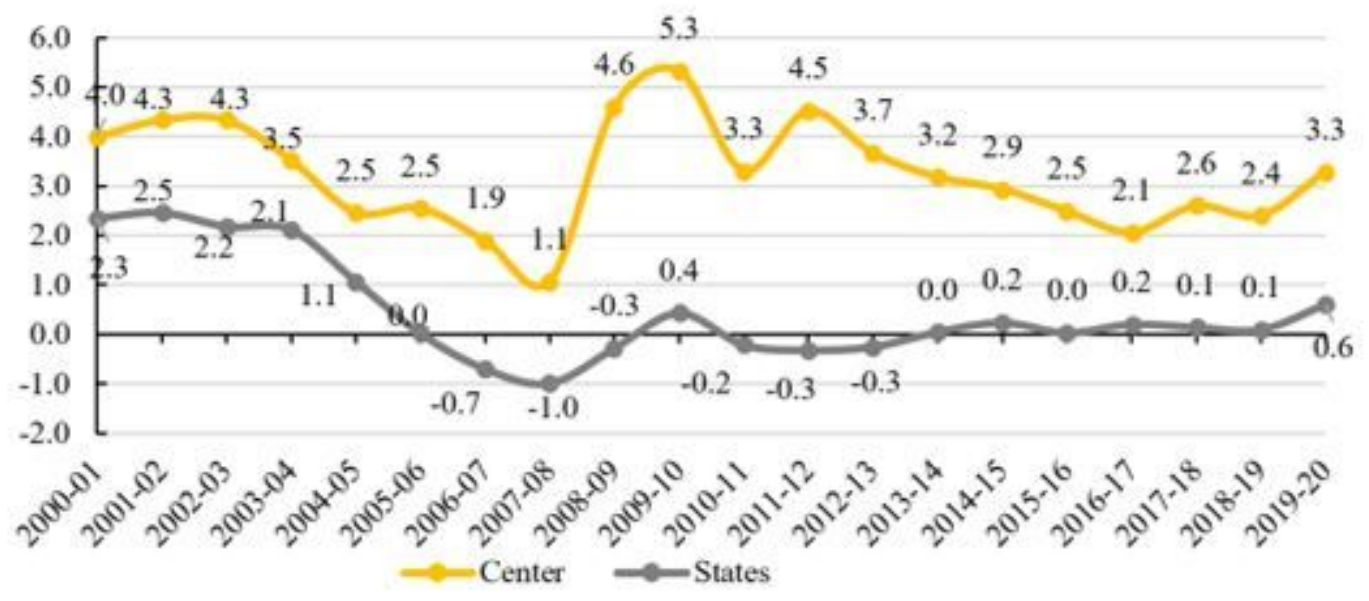

\section{Figure 2}

Revenue deficit (+) relative to GDP: Centre and states. Source (Basic Data): IPFS, CSO, RBI 2019-20 Annual Report (released 25 August 2020) Note: For states, data from 2016-17 onwards is sourced from the RBI where $2019-20$ pertains to RE. 


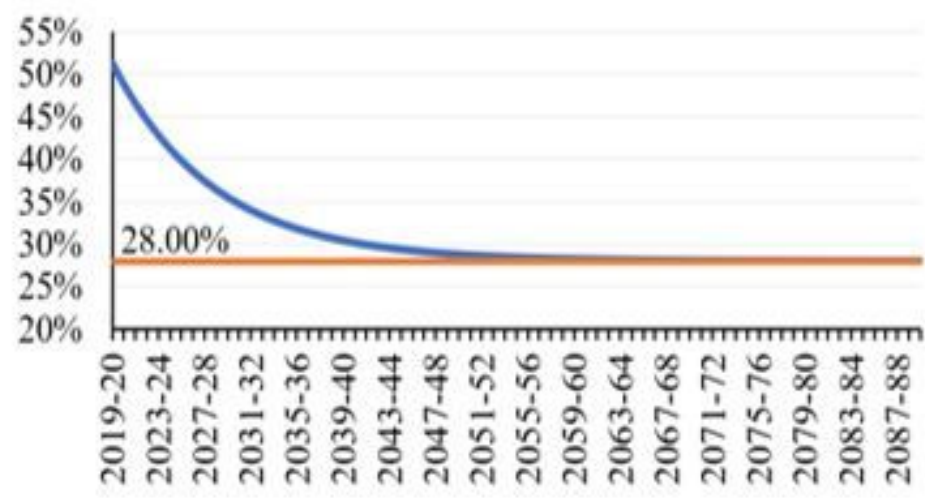

\section{Figure 3}

Centre's Debt-GDP ratio Source: RBI, MOSPI, and author's estimates; Note: Initial debt to GDP ratio for 2019-20 for the center was taken at 51.4\% (RE). Debt-GDP ratio for all states was taken at $23.1 \%$ (RE)

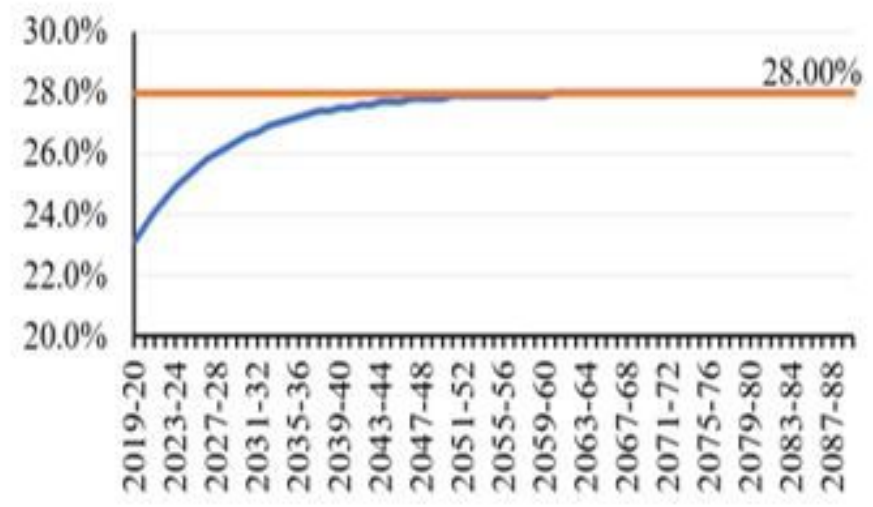

\section{Figure 4}

States Debt-GDP ratio Source: RBI, MOSPI, and author's estimates; Note: Initial debt to GDP ratio for 201920 for the center was taken at 51.4\% (RE). Debt-GDP ratio for all states was taken at $23.1 \%(\mathrm{RE})$

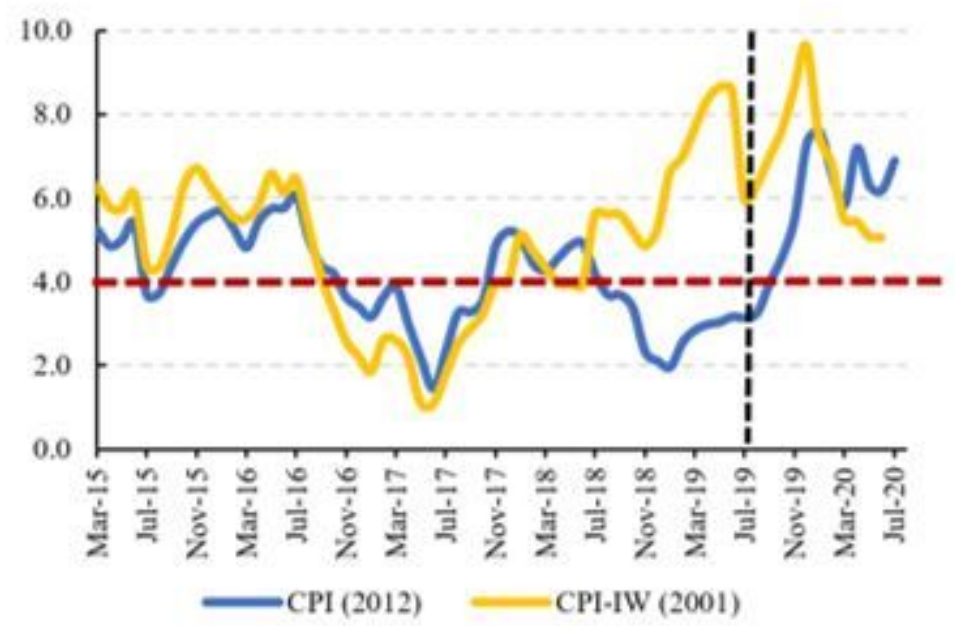




\section{Figure 5}

CPI inflation Source (basic data): MOSPI

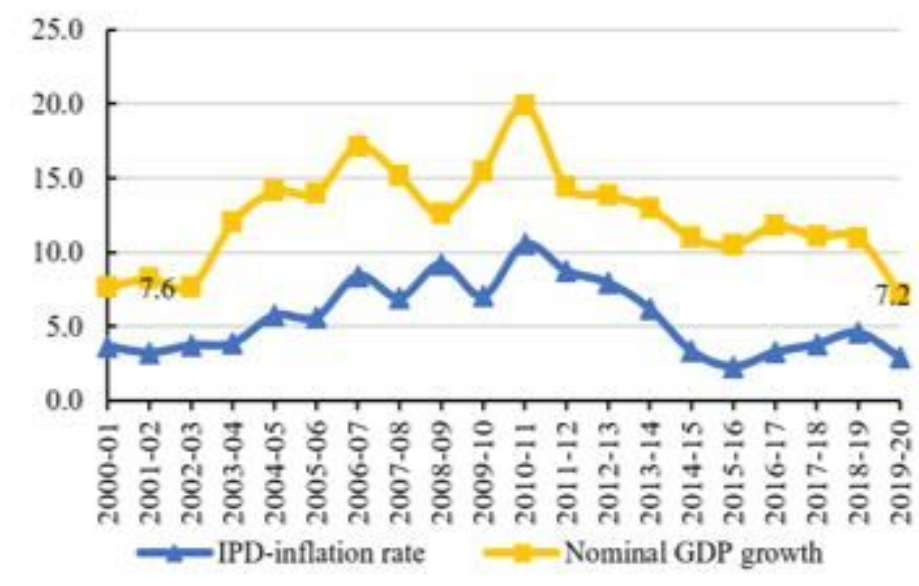

\section{Figure 6}

IPD based inflation and nominal GDP growth

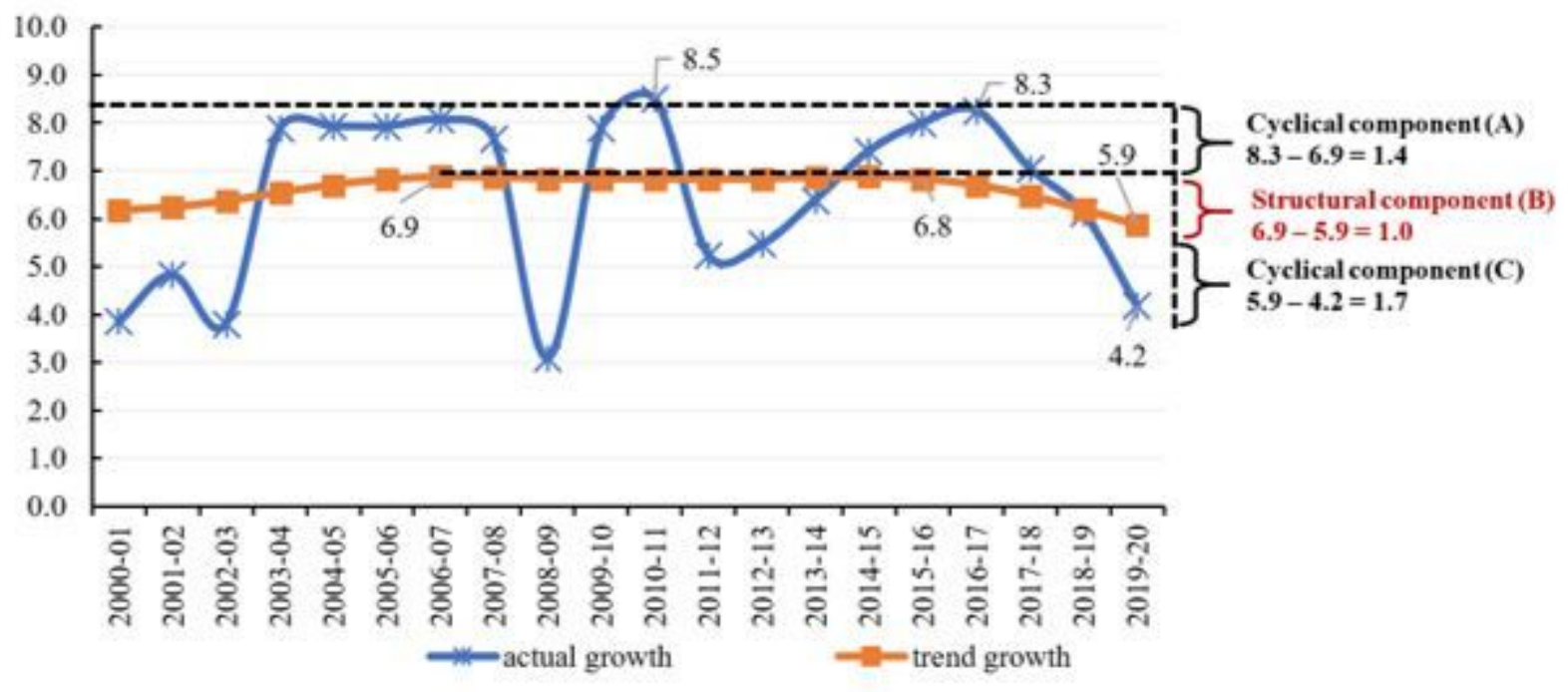

\section{Figure 7}

Real GDP growth: actual and trend Source: MOSPI; Note: the trend growth was estimated using HodrickPrescott filter using a lambda value of 50 


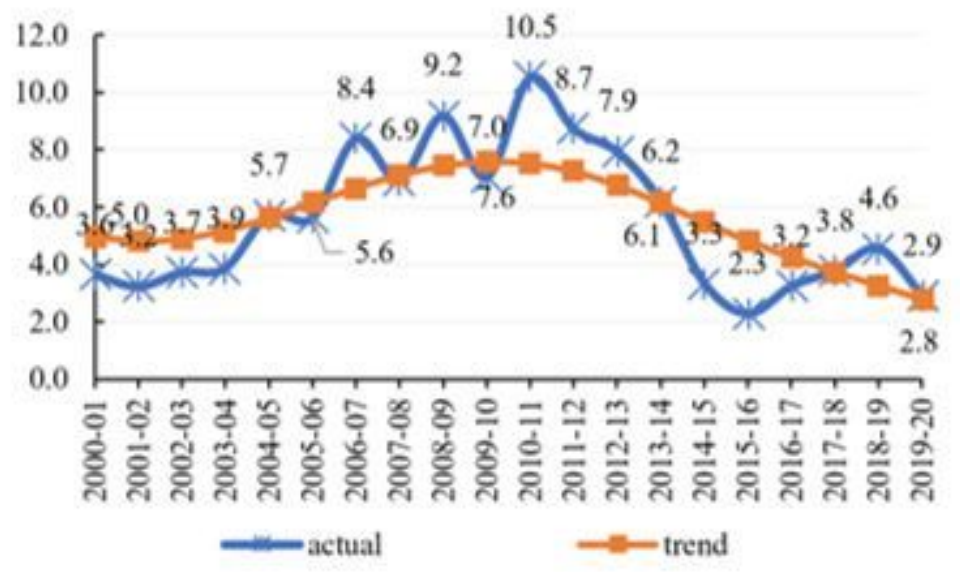

Figure 8

Deflator based inflation rate: actual and trend Source: MOSPI Notes: the trend growth was estimated using Hodrick-Prescott filter using a lambda value of 50

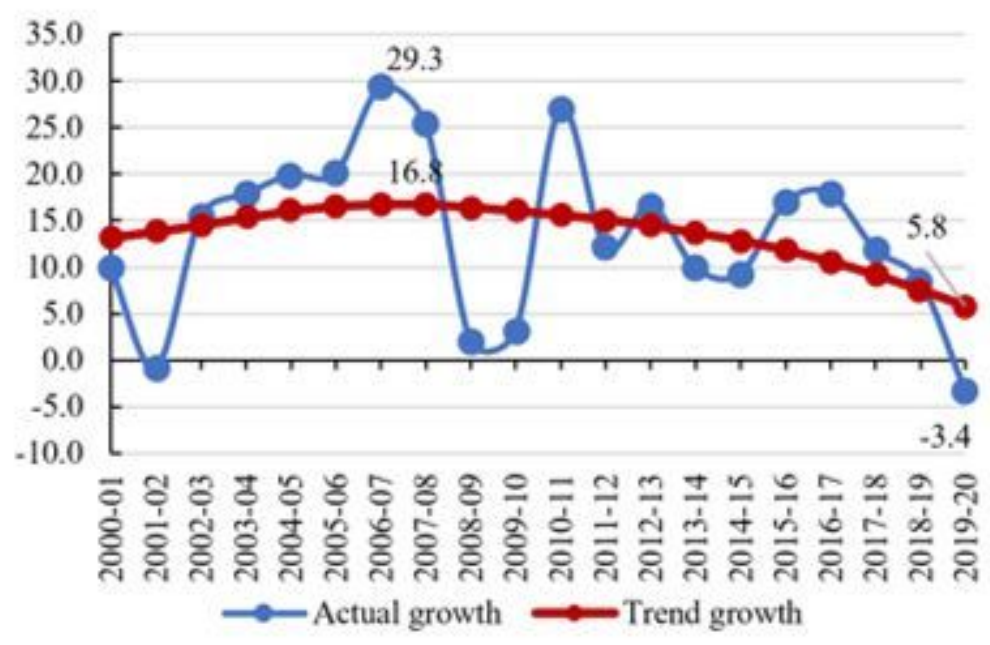

\section{Figure 9}

centre's GTR growth: trend and actual 


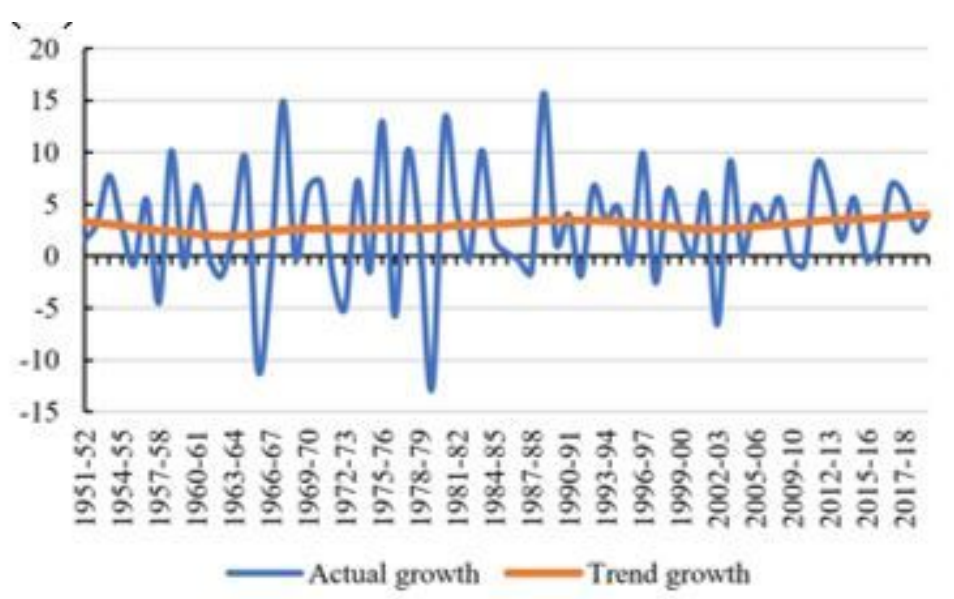

Figure 10

Real agricultural growth: actual and trend (\%) Source (basic data): MOSPI

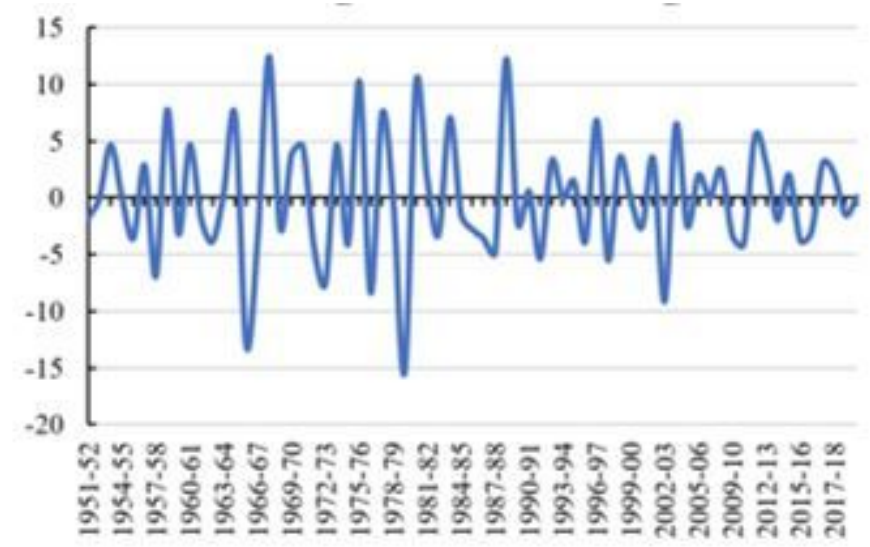

Figure 11

Cyclicality in agricultural growth: deviation of actual growth from trend growth (\% points) 